\title{
A new fish haemogregarine from South Africa and its suspected dual transmission with trypanosomes by a marine leech
}

\author{
Polly M. Hayes ${ }^{1}$, Nico J. Smit ${ }^{3,4}$, Alan M. Seddon ${ }^{1}$, David F. Wertheim ${ }^{2}$ and Angela J. Davies ${ }^{1}$ \\ ${ }^{1}$ School of Life Sciences and ${ }^{2}$ School of Computing and Information Systems, Kingston University, Kingston upon Thames, \\ Surrey KT1 2EE, UK; \\ ${ }^{3}$ Department of Zoology, University of Cape Town, Rondebosch, 7701, South Africa; \\ ${ }^{4}$ Department of Zoology, University of Johannesburg, P.O. Box 524, Auckland Park, 2006, South Africa
}

Key words: Haemogregarina curvata, trypanosomes, leeches, development, intertidal fishes, South Africa

\begin{abstract}
Twenty two percent (22/98) of intertidal fishes of 10 species captured in South Africa at Koppie Alleen, De Hoop Nature Reserve (south coast) and Mouille Point, Cape Town (west coast), harboured single or combined infections of haemogregarines, trypanosomes and an intraerythrocytic parasite resembling a Haemohormidium sp. The haemogregarines included the known species Haemogregarina (sensu lato) bigemina (Laveran et Mesnil, 1901) Siddall, 1995 and Haemogregarina (sensu lato) koppiensis Smit et Davies, 2001, while Haemogregarina (sensu lato) curvata sp. n. was observed in Clinus cottoides Valenciennes and Parablennius cornutus (L.) at Koppie Alleen. This last haemogregarine is characterised particularly by its distinctly curved gamonts. Also at Koppie Alleen, squash and histological preparations of 9/10 leeches, Zeylanicobdella arugamensis De Silva, 1963, taken from infected C. cottoides and P. cornutus contained developmental stages of $H$. curvata and/or trypanosomes, but these were absent from haematophagous gnathiid isopods (Gnathia africana Barnard, 1914) taken from infected fishes. It is suspected that Z. arugamensis transmits the haemogregarine and trypanosomes simultaneously between fishes, a double event unreported previously from the marine environment.
\end{abstract}

Knowledge of marine fish haematozoans from South Africa is limited. Two species of haemogregarines, Haemogregarina (sensu lato) bigemina (Laveran et Mesnil, 1901) Siddall, 1995 (see Smit and Davies 1999, Davies and Smit 2001, Smit et al. 2003) and Haemogregarina (sensu lato) koppiensis Smit et Davies, 2001 (see Smit and Davies 2001, 2005), and three of trypanosomes, Trypanosoma nudigobii Fantham, 1919, Trypanosoma capigobii Fantham, 1919, and Trypanosoma blenniclinii Fantham, 1930 (see Fantham 1919, 1930), are named from teleosts, while one trypanosome, Trypanosoma haploblephari Yeld et Smit, 2006, is reported from elasmobranchs (Yeld and Smit 2006). A Haemohormidium-like parasite also occurs in an intertidal teleost (Davies et al. 2003), and a dactylosomatid, a trypanosome and a Desseria sp. have been reported from brackish water mullet (Paperna 1996, Smit et al. 2002).

Haematophagous leeches and isopods have been identified as the likely vectors of some marine fish haemogregarines in the north western and north eastern Atlantic (see Davies 1995, Davies et al. 2004), but only leeches have been demonstrated to transmit trypanosomes in these regions (see Karlsbakk 2004). In South Africa, juvenile isopods of the genus Gnathia are likely vectors of $H$. bigemina (see Davies and Smit 2001). Leeches are not commonly reported from teleosts in this location (see Fantham 1919, 1930, Smit and Davies 1999, Davies et al. 2003, 2004), although they occur on elasmobranchs infected with T. haploblephari (Yeld and Smit 2006).
In 2003, intertidal fishes captured on the south and west coasts of South Africa were found to harbour single or mixed infections of haemogregarines, trypanosomes, and a Haemohormidium-like parasite. Among these, a haemogregarine new to science was discovered. Also, and unusually given previous observations, leeches were present on some infected fishes and developmental stages of a haemogregarine and trypanosomes were located in these invertebrates, suggesting simultaneous transmission of these blood parasites to fishes. Parasite stages found in both fishes and leeches are reported below, including a description of the new species of haemogregarine.

\section{MATERIALS AND METHODS}

Rock pool fishes were collected during low tides at Koppie Alleen, De Hoop Nature Reserve and at Mouille Point, Cape Town on the south and west coasts of South Africa in September and October 2003. To aid capture of fishes in large pools, these were drained with buckets, or alternatively clove oil (1-2\% in seawater) was squirted beneath loose rocks and in crevices as a fish anaesthetic (see Chanseau et al. 2002). Following capture with hand nets, fishes were maintained in buckets $(8 \mathrm{~L})$ of fresh, aerated seawater until examination, when they were identified and measured (total length, TL) using methods described elsewhere (Smit and Davies 1999), and examined for ectoparasites.

Blood films from fishes. In the laboratory, fishes were anaesthetised with clove oil (Chanseau et al. 2002) and films were prepared from blood taken directly from the heart or by 
snipping gill filaments. All blood smears were fixed in absolute methanol, stained with Giemsa's stain and screened for blood parasites using a $100 \times$ oil immersion objective on a Zeiss Axioskop photomicroscope. Microscopic images of blood parasites (or their invertebrate stages, see below) were captured by digital camera (Nikon DN100), stored on computer disks and measured with an Eclipse Net (Nikon) image analysis package, calibrated to a stage micrometer. [Such measurements, cited below, are in $\mu \mathrm{m}$, as means and standard deviation $( \pm \mathrm{SD})$, with ranges and numbers of observations (n) in parentheses.]

Ectoparasites. Leeches, found on the pectoral and pelvic fins of fishes at Koppie Alleen were identified as Zeylanicobdella arugamensis De Silva, 1963 (Hirudinea, Piscicolidae) by Professor E. Burreson (Virginia Institute of Marine Science, USA). When replete, these invertebrates were removed from fishes with fine brushes and placed singly, or in groups, in $50-\mathrm{ml}$ screw top jars of fresh seawater and maintained at 18 $22^{\circ} \mathrm{C}$ for up to 32 days post feeding (d.p.f.). Ten leeches $(9$ adults, 1 juvenile) were then examined either by squashing or as histological preparations (as below).

Squash preparations from 4 adult leeches held collectively until 1 d.p.f., and 3 more adult leeches held separately for 30 , 31 and 32 d.p.f., were fixed, stained and screened as for blood films (see above). Two more adult leeches at 1 d.p.f. were fixed intact in Karnovsky's fixative (Karnovsky 1965), while the juvenile $Z$. arugamensis was fixed whole in $4 \%$ neutral buffered formalin (NBF) immediately after feeding $(<1$ d.p.f.). Fixed, whole leeches were then prepared for standard histology and $6 \mu \mathrm{m}$ sections were stained with haematoxylin and eosin (H\&E), or Giemsa's stain. Mounted sections were examined by conventional brightfield microscopy, by differential interference contrast (DIC) or confocal microscopy (Leica TCS SP2 AOBS), if these latter methods enhanced detection of parasite stages within the invertebrates. Images were captured as for blood films or by confocal microscopy software (Leica).

Unfed (zuphea), partially fed (zuphea/praniza) and replete (praniza) juvenile gnathiid isopods, identified as Gnathia africana Barnard, 1914 (see Smit et al. 1999), were collected at both Koppie Alleen and Mouille Point. These isopods were retrieved from fishes or from collection buckets, graded according to instar (see Davies and Smit 2001), and 144 in total were placed in 50-ml jars of fresh seawater, and maintained under the same conditions as leeches for up to 32 d.p.f.

Squash/crush preparations of 60/144 whole gnathiid larvae (see Davies and Smit 2001) were prepared up to 26 d.p.f. and fixed, stained and screened as for blood films (above). The remaining gnathiids (84/144) were used in infection experiments, or for histological and transmission electron microscopy studies, none of which is reported here.

\section{RESULTS}

\section{General observations of blood parasites in fishes and ectoparasites}

The 98 fishes examined belonged to 10 species in 8 genera and 6 families (Table 1). Of these fishes, 5 species had haematozoa, including 3 species of haemogregarines, a variety of trypanosomes and an enigmatic intraerythrocytic parasite, which, in its early stages, resembled Haemohormidium Henry, 1910 (see Davies et al. 2003) (Table 1).

At Koppie Alleen, Clinus cottoides Valenciennes (13/47) harboured stages of a previously unreported haemogregarine (hereafter known as 'the new' haemogregarine): 5 fish had only the new haemogregarine; one the new haemogregarine and H. bigemina; and 7 the new haemogregarine and trypanosomes (one of these $C$. cottoides also had $H$. bigemina). A further 3 specimens of $C$. cottoides carried only trypanosome infections (Table 1). Parablennius cornutus (L.) (2/3) had mixed infections of the new haemogregarine, H. bigemina and trypanosomes, and 1/2 of these infected fishes also harboured the Haemohormidium-like parasite. Blennioclinus brachycephalus (Valenciennes) $(2 / 5)$ were infected with $H$. bigemina and Amblyrhynchotes honckenii (Bloch) carried stages of H. koppiensis (Table 1). Only one fish from Mouille Point was infected; Clinus agilis Smith had $H$. bigemina, trypanosomes and the Haemohormidium-like organism (Table 1).

Stages of the new haemogregarine from $C$. cottoides included intracellular trophozoites, intracellular and extracellular meronts, merozoites and gamonts, but only intraerythrocytic gamonts were detected in P. cornutus. Intensity of infection in $C$. cottoides was higher $(0.2-$ $0.5 \%$ of erythrocytes infected) than in $P$. cornutus $(<0.1 \%$ of erythrocytes infected). No intraleucocytic stages were seen.

Infection levels with $H$. bigemina, H. koppiensis and the Haemohormidium-like organism were very light $(<0.01 \%$ erythrocytes parasitized $)$, the parasite stages were indistinguishable morphologically from those previously described from South African fishes (Smit and Davies 1999, 2005, Davies and Smit 2001, Smit et al. 2002, 2003, Davies et al. 2004) and they are not considered further here. However, H. bigemina and the Haemohormidium-like organism have not previously been reported from $C$. agilis, representing a new host record for these haematozoans. This is also the first report of these parasites from the west coast of South Africa.

Developmental stages of fish blood parasites were observed in 9/10 Z. arugamensis. Squash preparations and histological sections of $8 / 9$ leeches from 9 C. cottoides (7.6-8.8 cm TL), and squashes of $1 / 1$ of the same leech from $P$. cornutus $(8.4 \mathrm{~cm} \mathrm{TL})$ were infected. Of 8 ( 7 adults and 1 juvenile) infected leeches from $C$. cottoides, squashes from 5 adults revealed one with haemogregarines (1 d.p.f.), two with trypanosomes (1 and 31 d.p.f.) and two with mixed infections (1 and 32 d.p.f). Furthermore, histological sections from two adults (1 d.p.f.) and the juvenile ( $<1$ d.p.f.) from C. cottoides showed all three leeches with trypanosomes and one adult leech with haemogregarines. Stages of the new haemogregarine observed in leech squashes and sections included gamont-like forms, oocysts at differ- 
Table 1. Sites of capture, identity, number and length of fishes collected at Koppie Alleen and Mouille Point, and prevalence of blood parasites in these fishes. Abbreviations: $\mathrm{n}$ - number, TL - total length, $\mathrm{SD}$ - standard deviation.

\begin{tabular}{|c|c|c|c|c|c|c|c|c|}
\hline \multirow{3}{*}{ Site } & \multirow{2}{*}{\multicolumn{3}{|c|}{ Fishes }} & \multicolumn{5}{|c|}{ Prevalence of blood parasites (\%) } \\
\hline & & & & \multicolumn{3}{|c|}{ Haemogregarines } & \multirow[b]{2}{*}{ Trypanosomes } & \multirow{2}{*}{$\begin{array}{c}\text { Haemohormidium- } \\
\text { like parasite }\end{array}$} \\
\hline & Species & $\mathrm{n}$ & $\begin{array}{c}\mathrm{TL} \pm \mathrm{SD} \\
\text { (range) in } \mathrm{cm}\end{array}$ & H. curvata & H. bigemina & H. koppiensis & & \\
\hline \multirow[t]{7}{*}{$\begin{array}{l}\text { Koppie } \\
\text { Alleen }\end{array}$} & $\begin{array}{l}\text { Amblyrhynchotes } \\
\text { honckenii }\end{array}$ & 1 & 8.7 & $0 / 1(0)$ & $0 / 1(0)$ & $1 / 1(100)$ & $0 / 1(0)$ & $0 / 1(0)$ \\
\hline & $\begin{array}{l}\text { Blennioclinus } \\
\text { brachycephalus }\end{array}$ & 5 & $\begin{array}{l}5.3 \pm 1.9 \\
(4.1-8.6)\end{array}$ & $0 / 5(0)$ & $2 / 5(40)$ & $0 / 5(0)$ & $0 / 5(0)$ & $0 / 5(0)$ \\
\hline & $\begin{array}{l}\text { Caffrogobius } \\
\text { nudiceps }\end{array}$ & 4 & $3,7.9,8.2,8.8$ & $0 / 4(0)$ & $0 / 4(0)$ & $0 / 4(0)$ & $0 / 4(0)$ & $0 / 4(0)$ \\
\hline & \begin{tabular}{|c|}
$\begin{array}{c}\text { Chirodactylus } \\
\text { brachydactylus }\end{array}$ \\
\end{tabular} & 2 & $5.5,6.1$ & $0 / 2(0)$ & $0 / 2(0)$ & $0 / 2(0)$ & $0 / 2(0)$ & $0 / 2(0)$ \\
\hline & \begin{tabular}{|l|} 
Clinus \\
cottoides
\end{tabular} & 47 & $\begin{array}{l}6.4 \pm 1.8 \\
(2.6-8.9) \\
\end{array}$ & 13/47 (28) & 2/47 (4) & 0/47 (0) & 10/47 (21) & $0 / 47(0)$ \\
\hline & \begin{tabular}{|l|} 
Clinus \\
superciliosus
\end{tabular} & 4 & $\begin{array}{c}3.3,3.4,4.4 \\
4.5\end{array}$ & $0 / 4(0)$ & $0 / 4(0)$ & $0 / 4(0)$ & $0 / 4(0)$ & $0 / 4(0)$ \\
\hline & $\begin{array}{c}\text { Parablennius } \\
\text { cornutus }\end{array}$ & 3 & $7.2,8.4,9.1$ & $2 / 3(67)$ & $2 / 3(67)$ & $0 / 3(0)$ & $2 / 3(67)$ & $1 / 3(33)$ \\
\hline \multirow{5}{*}{$\begin{array}{l}\text { Mouille } \\
\text { Point }\end{array}$} & Clinus agilis & 1 & 8 & $0 / 1(0)$ & $1 / 1(100)$ & $0 / 1(0)$ & $1 / 1(100)$ & $1 / 1(100)$ \\
\hline & $\begin{array}{l}\text { Clinus } \\
\text { cottoides }\end{array}$ & 21 & $\begin{array}{c}7.6 \pm 2.5 \\
(4.0-12.2)\end{array}$ & 0/21 (0) & 0/21 (0) & 0/21 (0) & 0/21 (0) & $0 / 21(0)$ \\
\hline & \begin{tabular}{|l|} 
Clinus \\
superciliosus
\end{tabular} & 2 & $5.2,6.6$ & $0 / 2(0)$ & $0 / 2(0)$ & $0 / 2(0)$ & $0 / 2(0)$ & $0 / 2(0)$ \\
\hline & $\begin{array}{l}\text { Chorisochismus } \\
\text { dentex }\end{array}$ & 5 & $\begin{array}{l}6.8 \pm 1.8 \\
(4.6-9.3) \\
\end{array}$ & $0 / 5(0)$ & $0 / 5(0)$ & $0 / 5(0)$ & $0 / 5(0)$ & $0 / 5(0)$ \\
\hline & $\begin{array}{l}\text { Muraenoclinus } \\
\text { dorsalis }\end{array}$ & 3 & $5.5,6.8,7.8$ & $0 / 3(0)$ & $0 / 3(0)$ & $0 / 3(0)$ & $0 / 3(0)$ & $0 / 3(0)$ \\
\hline Total & & 98 & & $15 / 98(15)$ & $7 / 98(7)$ & $1 / 98(1)$ & $13 / 98(13)$ & $2 / 98(2)$ \\
\hline
\end{tabular}

ent stages of development, sporozoites, meronts and two sizes of merozoites. One leech from $P$. cornutus (30 d.p.f.) contained only trypanosomes.

No blood parasites were detected in smears from 60/144 gnathiids (up to 26 d.p.f.) collected at Koppie Alleen and Mouille Point. Stages of the new haemogregarine observed in fishes and leeches are detailed below.

\section{Haemogregarina (sensu lato) curvata sp. n.}

\section{Description of fish blood stages}

Trophozoites. Small intraerythrocytic trophozoite stage (Fig. 1A), elongate, $4.4 \times 1.8(\mathrm{n}=1)$, one pole slightly narrower than the other. Cytoplasm staining pinkish-blue with Giemsa, nucleus comprising diffuse chromatin staining purple, situated towards broader (anterior?) pole of parasite body. Late trophozoites occurring singly in erythrocytes (Fig. 1B), elongate, with broad anterior and narrower, pointed, posterior, 8.0-9.0 $\times 2.0-2.5(\mathrm{n}=4)$. Cytoplasm staining light blue, nucleus, situated predominantly in posterior half, diffuse and staining purple.

Meronts. Young and more mature meronts in polychromatocytes and erythrocytes, and extracellularly (Fig. 1C, D). Young meronts (Fig. 1C) broader than trophozoites, blue cytoplasm and nuclei staining purple with coarse chromatin, $8.6 \pm 0.3(8.0-8.8) \times 3.1 \pm 0.5$ $(2.4-4.0)(\mathrm{n}=6)$. Extracellular meronts (Fig. 1D) lying close to host erythrocytes or polychromatocytes; broadest forms, $8.2 \pm 0.7(7.4-9.2) \times 3.6 \pm 0.7(2.9-4.7)(\mathrm{n}=$
5). Cytoplasm staining dark blue; sometimes with pink granules; nucleus staining pink-purple, granular, located towards narrower (posterior?) end of the parasite.

Merozoites. Extracellular merozoites single, or in groups of 4-7, lying close to host erythrocytes or polychromatocytes (Fig. 1E, F). Stages uniform in appearance, one rounded pole, other occasionally bluntly pointed, $6.5 \pm 0.6(5.5-7.5) \times 2.6 \pm 0.3(2.0-3.7)(\mathrm{n}=$ 21). Cytoplasm staining pale blue, nucleus granular and staining pink, situated centrally or towards either pole of merozoite.

Pregamonts. Intraerythrocytic, close to host cell nucleus, 9.7-11.2 × 2.8-3.3 $(\mathrm{n}=4)$. Broad anterior end, pointed posterior, pale blue stained cytoplasm generally, sometimes staining slightly pinkish. Nucleus with diffuse chromatin staining deep purple, situated towards broader pole of parasite (Fig. 1G).

Gamonts. Gamonts of three kinds, namely broad immature, intermediate and slender mature, characteristically comma or 'c' shaped (Fig. 1H-J). All three types single in host erythrocytes and generally curved around host nucleus.

Immature gamonts elongate, broad rounded anterior, tapering to narrow tail-like posterior (Fig. 1H), $12.3 \pm$ 0.9 (11.1-13.9) long overall $\times 3.1 \pm 0.4(2.6-3.9)(\mathrm{n}=$ 12) at their widest. Cytoplasm staining pale blue, with one or two vacuoles sometimes present towards more slender (posterior) end. Nucleus, with diffuse chromatin, lying in anterior two thirds of parasite, $3.3 \pm 0.7$ $(2.3-5.0) \times 2.6 \pm 0.3(2.2-3.1)(n=12)$. 
Intermediate gamonts more slender than immature forms (Fig. 1I), bluntly pointed anterior end and longer, slender tail-like posterior, $12.0 \pm 0.8$ (10.9-13.9) long overall by $2.4 \pm 0.4(1.9-3.3)(\mathrm{n}=20)$ at their widest. Cytoplasm staining blue. Nucleus situated in broad anterior of cell, but more condensed than in less mature forms, and as wide, or wider, than the main body of the parasite $3.0 \pm 0.4(2.4-3.4) \times 2.4 \pm 0.4(1.8-3.3)(\mathrm{n}=$ 20).

Mature gamonts monomorphic, with short, broad, bluntly pointed anterior portion, $7.5 \pm 0.7$ (6.3-7.9) long $\times 1.7 \pm 0.6(0.9-2.3)$ wide, and a long, distinct eosinophilic tail-like posterior, $6.1 \pm 0.5(5.7-6.8)(\mathrm{n}=5)$. Total length of gamont $13.5 \pm 0.6(12.6-14.4) \times 1.7 \pm 0.6$ $(0.9-2.3)(\mathrm{n}=5)$. Nucleus rounded or slightly oval, compact, stained deep purple, $2.7 \pm 0.5(2.3-3.3) \times 1.9$ $\pm 0.4(1.4-2.3)(\mathrm{n}=5)$, situated anteriorly, sometimes wider than the parasite body (Fig. 1J).

\section{Description of leech stages}

Gamonts. Free gamont-like stages, similar to those in blood smears, in leech squashes at 1, 31 and 32 d.p.f., measuring $11.2 \pm 0.6(10.5-12.2) \times 1.9 \pm 0.2(1.6-2.3)$ $(\mathrm{n}=10)$. Pairing of gamonts (syzygy) not observed.

Oocysts. Immature oocysts free of any host tissue in squashes at 1 d.p.f. and 31 d.p.f., round, blue staining cytoplasm, 10.9-12.1 in diameter $(n=4)$. Small, single, nucleus staining deep magenta, centrally placed or positioned to one side of the oocyst (Fig. 1K).

Maturing oocysts, loosely associated with host gut tissue, in squash at 31 d.p.f., both $14 \mu \mathrm{m}$ in diameter (n $=2$ ). Oocyst cytoplasm and multiple nuclei $(8-10$ ?) stained as in the younger oocysts (Fig. 1L).

Sporozoites. In squashes, free or loosely associated with host tissue at 1, 31 and 32 d. p. f. (Fig. 1M, N). Broad, sometimes curved, with rounded or bluntly pointed extremities. These stages measuring $9.9 \pm 0.6$ $(8.0-10.9) \times 3.0 \pm 0.5(2.5-4.2)(\mathrm{n}=21)$. Cytoplasm pale staining and granulated. Pink staining nucleus with diffuse chromatin, situated centrally or nearer to one pole; single vacuole anterior or posterior to nucleus. low).

Meronts. Seen only in histological sections (see be-

Merozoites. Merozoites of two sizes at 1, 31 and 32 d.p.f. All free of host tissue. Larger (first generation ?), bluish staining, curved forms, $8.5 \pm 0.7(7.3-10) \times 2.0 \pm$ $0.4(1.4-2.7)(\mathrm{n}=22)$. Nucleus placed centrally or towards one end. Cytoplasm pink staining at either one or both extremities (Fig. 1O, P). Smaller (second generation ?) curved types at 1 d.p.f. with rounded extremities, $5.3 \pm 0.4(4.7-5.9) \times 2.0 \pm 0.2(1.8-2.2)(\mathrm{n}=5)$. Dark staining nucleus centrally placed (Fig. 1Q).

\section{Histopathology of leech stages}

Sporozoites and merozoites were detected in tissue adjacent to, and within, the dorsal sinus. Sporozoites, rounded and oval meronts, and merozoites also occurred in the salivary gland cells close to the proboscis (protru- sible pharynx). Infected salivary cells appeared enlarged compared with their uninfected neighbours, and they lacked the cellular contents seen in uninfected host cells (Fig. 1R, S). The haemogregarine stages were marginally arranged or lay free within salivary cells (Fig. 1S, T).

Ty pe mate ri a 1: Hapantotype slides: in the collection of the South African Museum, Cape Town (Fish blood film with mature gamonts of $H$. curvata, SAM A25084; Fish blood film with small trophozoite, extracellular merozoites, gamonts, SAM A25085; Fish blood film with pregamonts, intracellular and extracellular meronts, gamonts, SAM A25086; Leech smear with maturing oocyst, sporozoites, merozoites, SAM A25087; Histological leech section with sporozoites, merozoites, meronts in salivary gland cells, SAM A25088). In the collection of the Institute of Parasitology, ASCR, České Budějovice, Czech Republic (Fish blood smear with gamonts), Cat. No. DPF-010.

T y p e 1 o c a 1 i ty: Koppie Alleen, De Hoop Nature Reserve ( $\left.34^{\circ} 28^{\prime} \mathrm{S}, 20^{\circ} 30^{\prime} \mathrm{E}\right)$.

T y p e hosts: Clinus cottoides Valenciennes, 1836 (Actinopterygii: Perciformes: Clinidae) and Zeylanicobdella arugamensis De Silva, 1963 (Hirudinea: Piscicolidae).

O t h e r h o s t s : Parablennius cornutus (Linnaeus, 1758) (Actinopterygii: Perciformes: Blenniidae).

S i t e of infection: Heart blood of $C$. cottoides and $P$. cornutus; dorsal sinus and salivary glands of Zeylanicobdella arugamensis.

$\mathrm{O} t \mathrm{~h}$ e r m a te ria $1:$ In the collection of the authors $(12 C$. cottoides blood films; 2 P. cornutus blood films; 2 Z. arugamensis smears; histological material).

E t y m o 1 o g y : The specific name refers to the distinct, curved shape of the gamont stages.

\section{Remarks}

Haemogregarina curvata is characterised by its curved monomorphic gamont, with its anterior nucleus and elongate, eosinophilic tail. It is distinct from $H$. bigemina and $H$. koppiensis, previously reported from rock pool fishes in South Africa (Smit and Davies 1999, 2001, 2005, Davies and Smit 2001, Smit et al. 2003); it is also unlike the Desseria species known from brackish water mullet (Mugil cephalus L.) in southern Africa (Smit et al. 2002). Haemogregarina curvata does not resemble any other known species of fish haemogregarine (see Davies 1995).

The existence of extracellular merozoites in blood films, presumably derived from the division of intracellular meronts, suggests that the haemogregarine could belong to the genus Cyrilia Lainson, 1981 or Haemogregarina (sensu lato) Danilewsky, 1885, but not Desseria Siddall, 1995, according to a partially revised systematics of fish haemogregarines (Siddall 1995). However, its vertebrate hosts are marine fishes and the developmental stages demonstrated in $Z$. arugamensis, removed from host fishes infected with $H$. curvata, support the inclusion of this haemogregarine in Haemogregarina (sensu lato) (see general discussion). 


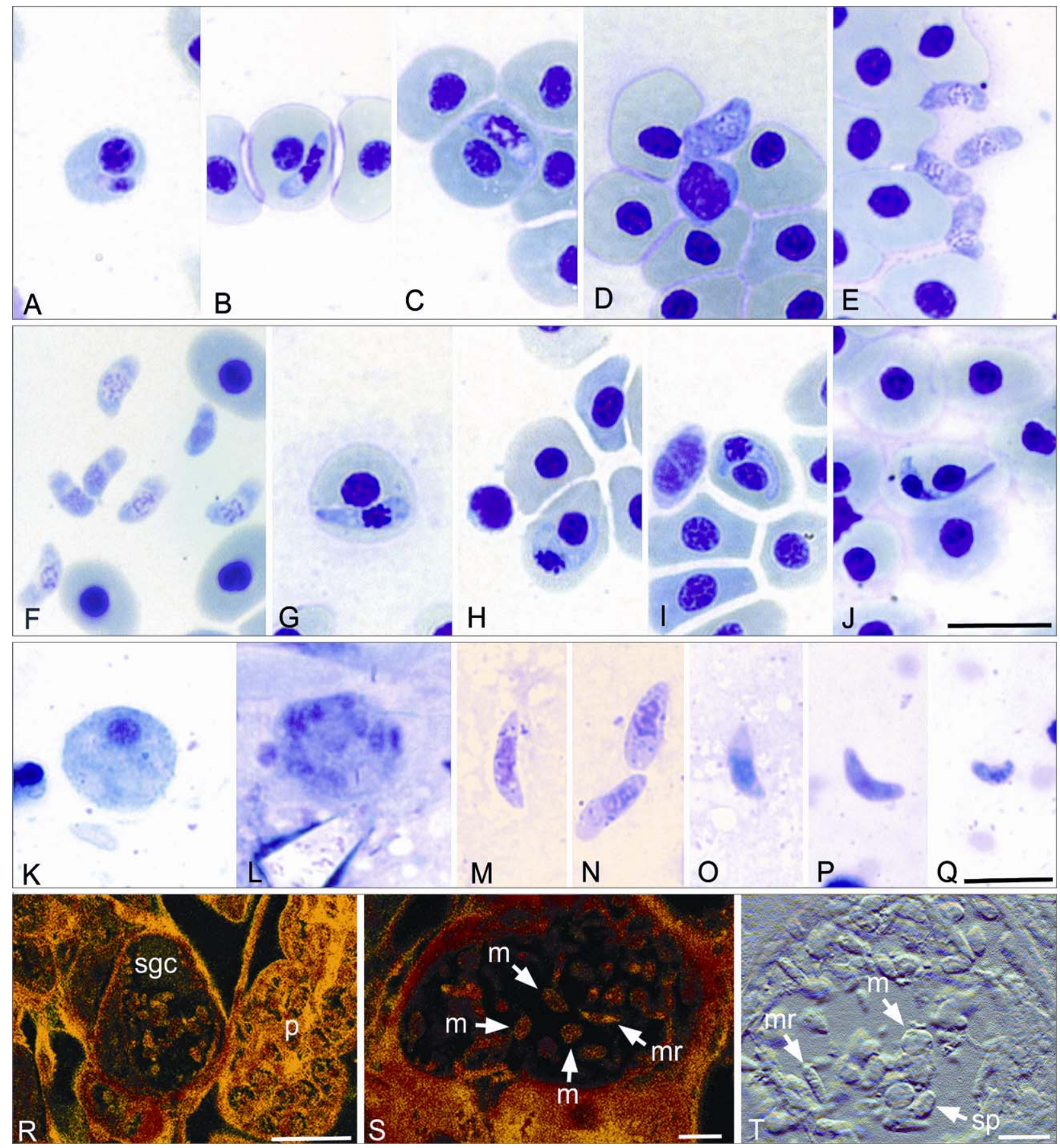

Fig. 1. Developmental stages of Haemogregarina curvata in Giemsa-stained fish blood films (A-J) and Zeylanicobdella arugamensis squashes (K-Q). Confocal (R, S) and DIC (T) images of histological sections showing haemogregarine stages in salivary gland cells of $Z$. arugamensis. A - small trophozoite; $\mathbf{B}$ - larger trophozoite; $\mathbf{C}$ - intraerythrocytic meront; $\mathbf{D}$ - extracellular meront; E, F - extracellular merozoites; $\mathbf{G}$ - pregamont form; $\mathbf{H}$ - immature gamont; I - intermediate gamont; J - mature gamont, note eosinophilic tail; $\mathbf{K}$ - immature oocyst; $\mathbf{L}$ - developing oocyst with 8-10 nuclei; $\mathbf{M}, \mathbf{N}$ - free sporozoites; $\mathbf{O}, \mathbf{P}$ - first generation merozoites; $\mathbf{Q}$ - second generation merozoite; $\mathbf{R}$ - infected salivary gland cell (sgc) adjacent to proboscis $(\mathrm{p}) ; \mathbf{S}, \mathbf{T}-$ infected salivary gland cells with meronts (m), merozoites (mr) and sporozoites (sp). Scale bars: A-J $=10 \mu \mathrm{m} ; \mathrm{K}-\mathrm{Q}=10 \mu \mathrm{m}$; $\mathrm{R}=20 \mu \mathrm{m} ; \mathrm{S}, \mathrm{T}=10 \mu \mathrm{m}$. 


\section{Trypanosome infections in fishes and leeches}

Trypanosome infections were light in most blood smears examined ( $\sim 5$ trypanosomes/blood film) and the flagellates varied in staining properties. Small and large trypanosomes formed mixed populations in most blood films from 10/47 C. cottoides and in 1/2 infected $P$. cornutus, while large trypanosomes dominated infections in C. agilis.

In leech squashes, the developmental stages of trypanosomes included amastigotes, sphaeromastigotes, a few promastigotes, epimastigotes, and some metacyclic types. Developmental forms were also located in histological sections. Amastigotes occurred in the crop and intestine of one adult leech, and epimastigotes in the intestine of two adults and one juvenile. In addition, numerous long, slender, epimastigotes were located in the dorsal sinus (dorsal coelomic cavity) of both adult leeches.

\section{Remarks}

The trypanosomes in fish blood films resembled all three species previously described by Fantham (1919, 1930), although none was observed in C. nudiceps (see Fantham 1919) and some were detected in additional fish species, namely $C$. agilis and $C$. cottoides. Since our trypanosomes were similar to T. nudigobii, T. blenniclini and $T$. capigobii, mixed infections may have been witnessed, or they may all be polymorphic forms of $T$. nudigobii, which was described first (Fantham 1919); T. blenniclini and T. capigobii may thus be synonyms of $T$. nudigobii. The morphometrics, identity and development of these trypanosomes in both fish and leech hosts will be described in detail elsewhere (Davies et al., in preparation).

\section{DISCUSSION}

Although not recorded previously from South Africa (see De Silva 1963, De Silva and Fernando 1965, Sanjeeva et al. 1977, Cruz-Lacierda et al. 2000), Zeylanicobdella arugamensis may be synonymous with Malmania (Ottoniobdella) stellata Moore, 1958 from the Natal coast (see Moore 1958, Burreson E., Virginia Institute of Marine Science, USA; pers. comm.). Since the leech was taken from fishes containing haematozoans in the current study, the developmental forms seen in $Z$. arugamensis squashes and histological sections are likely those of infections from the fishes. Furthermore, the distribution d.p.f. of the various haemogregarine and trypanosome stages in $Z$. arugamensis suggests a mixture of old and new infections.

Fish haemogregarines are currently classified in three genera, Cyrilia Lainson, 1981 from freshwater fishes, and Desseria Siddall, 1995 and Haemogregarina (sensu lato) Danilewsky, 1885 from freshwater and marine fishes; Haemogregarina (sensu stricto) is reserved for chelonian haemogregarines (see Siddall 1995). Distinctions between these generally rely on the course of development of the haemogregarine in both vertebrate and invertebrate hosts. Cyrilia spp. and Haemogregarina spp. exhibit intraerythrocytic division, while Desseria spp. are apparently devoid of erythrocytic merogony (Siddall 1995). Cyrilia spp. and Desseria spp. also undergo development in leeches, while of two species classified in Haemogregarina (sensu lato), one, Haemogregarina (sensu lato) uncinata (Khan, 1978) Siddall, 1995, develops in a leech, the other, H. bigemina in gnathiid isopods (Siddall 1995, Davies and Smit 2001).

In Cyrilia spp. sporogony in leech intestinal epithelial cells produces 20 or more naked sporozoites and the development of $H$. uncinata is apparently similar (Lainson 1981, Negm-Eldin 1999). In Desseria spp. sporogony in leeches yields 16 or more naked sporozoites, but this is followed by primary merogony in leech intestinal cells producing 4 merozoites (Siddall 1995). For $H$. bigemina oocysts produce around 5 sporozoites in gnathiid isopods and three generations of merogony likely follow sporogony (Davies and Smit 2001). Chelonian Haemogregarina (sensu stricto) spp. exhibit gametogenesis and sporogony in leech intestinal epithelium, oocysts produce 8 or more naked sporozoites and post-sporogonic production of merozoites is extraintestinal (Siddall 1995).

The development stages of haemogregarines seen in $Z$. arugamensis in the current study are unlikely those of Haemogregarina koppiensis which occurs in the evileye pufferfish Amblyrhynchotes honckenii (see Smit and Davies 2001, 2005); the leech was not found on this fish. Furthermore, gnathiid isopods host the development of $H$. bigemina in South Africa and elsewhere (Davies 1995, Davies and Smit 2001), and this development is unlike that seen in $Z$. arugamensis (see above). Although Gnathia africana juveniles occurred on fishes harbouring haematozoans in the current study, there was no evidence of any development stages in these crustaceans on this occasion.

Evidence suggests that the leech stages seen in the present material must be those of Haemogregarina curvata, which was the predominant haemogregarine seen in fish blood smears (Table 1). Its apparent merogony in fish blood, oocysts with 8-10 developing sporozoite nuclei and likely post-sporogonic merogony producing at least 2 generations of morphologically distinct types of merozoites supports the inclusion of $H$. curvata in the genus Haemogregarina (sensu lato), at the least. Its additional occurrence in the intestine, dorsal sinus and in the salivary glands of $Z$. arugamensis, further suggests a strong affinity with Haemogregarina (sensu stricto) from chelonians. Interestingly in $Z$. arugamensis, infected salivary gland cells appeared larger than uninfected cells, and their cellular contents were lacking, indicating a possible pathogenic effect on the invertebrate host.

The additional detection of trypanosome infections in this study was surprising, given the apparent absence of these flagellates from fishes and paucity of leeches on the southern coast of South Africa in recent years (Smit 
and Davies 1999, 2001, Davies and Smit 2001, Davies et al. 2003, Smit et al. 2003). The trypanosome developmental forms observed in $Z$. arugamensis are typical of those reported from marine leeches in the northern hemisphere (see Brumpt 1904, 1906, Robertson 1907, 1909, Neumann 1909, Khan 1976, 1978a, b). Trypanosome stages were also found in both a juvenile and adult $Z$. arugamensis, suggesting that flagellates are acquired at a young age and sustained into adulthood in these annelids.

As for H. curvata, Z. arugamensis is the likely vector of the trypanosomes, although biological transmission has not yet been demonstrated for either type of infection under laboratory conditions. The process of migration and invasion of the leech proboscis by fish haemogregarines and trypanosomes has not been fully elucidated for any infections of this type. In leeches in the current study, sporozoite and merozoite stages of $H$. curvata were seen in tissues adjacent to the dorsal sinus and near the epithelial lining of this structure; unusually, large numbers of long slender epimastigotes were also observed in the same sinus. These haematozoans may thus migrate, or be transported, to the proboscis (protrusible pharynx) through the dorsal sinus, which includes the dorsal blood vessel. In rhynchobdellid leeches, the dorsal sinus connects to ventral and paired lateral sinuses, through communicating ducts, and to a network of coelomic sinuses or cavities, including the medial haemocoelomic sinus which lies adjacent to the proboscis and in which the salivary glands are located (Fernández et al. 1992). Siddall and Desser (1993), and
Siddall and Burreson (1994) both reported developmental stages of fish haemogregarines in the sinus system of marine leeches. Chelonian haemogregarines have also been detected in the blood sinuses of leech vectors (Seigel 1903, Robertson 1910, Siddall and Desser 1991). Stages of $H$. curvata, but not trypanosomes, were also observed in the salivary gland cells of $Z$. arugamensis in close proximity to the proboscis. These forms resembled those of fish haemogregarines described from the salivary gland cells of other marine leeches (So 1972, Khan et al. 1980, Siddall and Desser 1991, 1993, 2001).

To our knowledge, haemogregarines and trypanosomes have not been reported from marine leeches in the southern hemisphere previously. Furthermore, detection of developmental stages of both types of haematozoans in $Z$. arugamensis taken from infected fishes suggests that the leech may transmit the infections simultaneously. Examples of such dual haemogregarine/trypanosome vector activity have been rarely observed (Lainson 1981, Negm-Eldin and Davies 1999), and then in freshwater systems, thus highlighting the unusual nature of our observations in a marine system in South Africa.

Acknowledgements. The authors are grateful to Prof. E. Burreson (Virginia Institute of Marine Science, USA) for identifying the leech in this study. A.J.D. gratefully acknowledges a study abroad grant from The Royal Society and N.J.S. funding from The Claude Harris Leon Foundation and the University of Johannesburg's Sasol Research Fund.

\section{REFERENCES}

BECKER J.R., OVERSTREET R.M. 1979: Haematozoa of marine fishes from the northern Gulf of Mexico. J. Fish Dis. 2: 469-479.

BRUMPT E. 1904: Contribution á l'étude d'évolution des hémogrégarines et des trypanosomes. C. R. Soc. Biol. 57: $165-167$.

BRUMPT E. 1906: Mode de transmission et evolution des trypanosomes des poisons. Descriptions de quelques espèces de trypanoplasmes des poisons d'eau douce. Trypanosome d'un crapaud africain. C. R. Soc. Biol. 60: 162164.

CHANSEAU M., BOSC S., GALIAY E., OULES G. 2002: L'utilisation de l'huile de clou de girofle comme anesthésique pour les smolts de saumon atlantique (Salmo salar L.) et comparaison de ses effets avec ceux du 2Phénoxyethanol. Bull. Fr. Peche Piscic. 365/366: 579589.

CRUZ-LACIERDA E.R., TOLEDO J.D., TAN-FERMIN J.D., BURRESON E.M. 2000: Marine leech (Zeylanicobdella arugamensis) infestation in cultured orange-spotted grouper, Epinephelus coioides. Aquaculture 185: 191-196.

DAVIES A.J. 1995: The biology of fish haemogregarines. Adv. Parasitol. 36: 118-203.
DAVIES A.J., REED C.C., SMIT N.J. 2003: An unusual intraerythrocytic parasite of Parablennius cornutus from South Africa. J. Parasitol. 89: 913-917.

DAVIES A.J., SMIT N.J. 2001: The life cycle of Haemogregarina bigemina (Adeleina: Haemogregarinidae) in South African hosts. Folia Parasitol. 48:169-177.

DAVIES A.J., SMIT N.J., HAYES P.M., SEDDON A.M., WERTHEIM D.F. 2004: Haemogregarina bigemina (Protozoa: Apicomplexa: Adeleorina) - past present and future. Folia Parasitol. 51: 99-108.

DE SILVA P.H.D.H. 1963: Zeylanicobdella arugamensis gen. nov. and sp. nov. from Arugam Kalapu, Eastern Province, Ceylon. Spolia Zeylan. 30: 46-53.

DE SILVA P.H.D.H., FERNANDO C.H. 1965: Three marine leeches (Piscicolidae, Hirudinea) from the Malay Peninsula. Spolia Zeylan. 30: 227-232.

FANTHAM H.B. 1919: Some parasitic protozoa found in South Africa. S. Afr. J. Sci. 16: 195-191.

FANTHAM H.B. 1930: Some parasitic protozoa found in South Africa. S. Afr. J. Sci. 27: 376-390.

FERNÁNDEZ J., TÉLLEZ V., OLEA N. 1992: Hirudinea. In: F.W. Harrison and S.L. Gardiner (Eds.), Microscopic Anatomy of Invertebrates. Vol. 7. Wiley-Liss, New York, USA, pp. 323-394. 
KARNOVSKY M.J. 1965: A formaldehyde-glutaraldehyde fixative of high osmolarity for use in electron microscopy. J. Cell Biol. 27: 137a-138a.

KHAN R.A. 1976: The life cycle of Trypanosoma murmanensis Nikitin. Can. J. Zool. 54: 1840-1849.

KHAN R.A. 1978a: A redescription of Trypanosoma cotti Brumpt and Lebailly, 1904 and its development in the leech, Calliobdella punctata. Ann. Parasitol. 53: 461-466.

KHAN R.A. 1978b: Longevity of Trypanosoma murmanensis in the leech, Johanssonia sp. Can. J. Zool. 56: 2061-2063.

KHAN R.A., BARRETT M., MURPHY J. 1980: Blood parasites of fish from the northwestern Atlantic Ocean. Can. J. Zool. 58: 770-781.

KARLSBAKK E. 2004: A trypanosome of Atlantic cod, Gadus morhua L., transmitted by the marine leech Calliobdella nodulifera (Malm, 1863) (Piscicolidae). Parasitol. Res. 93: 155-158.

LAINSON R. 1981: On Cyrilia gomesi (Neiva \& Pinto, 1926) gen. nov. (Haemogregarinidae) and Trypanosoma bourouli Neiva \& Pinto, in the fish Synbranchus marmoratus: simultaneous transmission by the leech Haementeria lutzi. In: E.U. Canning (Ed.), Parasitological Topics. A presentation volume to P.C.C. Garnham, FRS on the occasion of his $80^{\text {th }}$ birthday 1981. Allen Press for the Society of Protozoologists (Special Publications No. 1), Lawrence, Kansas, pp. $150-158$.

MOORE J.P. 1958: The leeches (Hirudinea) in the collection of the Natal Museum. Ann. Natal Mus. 14: 303-340.

NEGM-ELDIN M.M. 1999: Life cycle, host restriction and longevity of Cyrilia nili (Haemogregarina nili Wenyon, 1909) n. comb. Dtsch. Tierärztl. Wochenschr. 106: 191199.

NEGM-ELDIN M.M., DAVIES R.W. 1999: Simultaneous transmission of Trypanosoma mukasai, Babesiosoma mariae and Cyrilia nili to fish by the leech Batracobdelloides tricarinata. Dtsch. Tierärztl. Wochenschr. 106: 526-527.

NEUMANN R.O. 1909: Studien über protozoische Parasiten im Blute von Meeresfischen. Z. Hyg. Infektionskr. 64: 1112.

PAPERNA I. 1996: Parasites, infections and diseases of fish in Africa. An update: Food and Agriculture Organization of the United Nations, Rome, 220 pp. [CIFA Technical Paper, no. 31]

ROBERTSON M. 1907: Studies on a trypanosome found in the alimentary canal of Pontobdella muricata. Proc. R. Phys. Soc. Edinb. 17: 83-108.

ROBERTSON M. 1909: Further notes on a trypanosome found in the alimentary tract of Pontobdella muricata. Q. J. Microsc. Sci. 54: 119-139.

ROBERTSON M. 1910: Studies on Ceylon haematozoa. No. II - Notes on the life cycle of Haemogregarina nicoriae, Cast and Willey. Q. J. Microsc. Sci. 55: 741-762.
SANJEEVA RAJ P.J., JAYADEV BABU S., GLADSTONE M. 1977: Anatomical details of two fish leeches from the Pulicat Lake, South India. J. Mar. Biol. Assoc. India 19: 35-43.

SEIGEL J. 1903: Die geschlechtliche Entwicklung von Haemogregarina stepanowi im Rüsselegel Pontobdella catenigra. Arch. Protistenkd. 2: 339-342.

SIDDALL M.E. 1995: Phylogeny of adeleid blood parasites with a partial systematic revision of the haemogregarine complex. J. Eukaryot. Microbiol. 42: 116-125.

SIDDALL M.E., BURRESON E.M. 1994: The development of a haemogregarine of Lycodes raridens from Alaska in its definitive leech host. J. Parasitol. 80: 569-575.

SIDDALL M.E., DESSER S.S. 1991: Merogonic development of Haemogregarina balli (Apicomplexa, Adeleina, Haemogregarinidae) in the leech Placobdella ornata (Glossiphoniidae), its transmission to a chelonian intermediate host and phylogenetic implications. J. Parasitol. 77: 426-436.

SIDDALL M.E., DESSER S.S. 1993: Ultrastructure of merogonic development of Haemogregarina (sensu lato) $m y$ oxocephali (Apicomplexa: Adeleina) in the marine leech Malmania scorpii and localization of the infective stages in the salivary cells. Eur. J. Protistol. 29: 191-201.

SMIT N.J., DAVIES A.J. 1999: New host records for Haemogregarina bigemina from the coast of Southern Africa. J. Mar. Biol. Assoc. U.K. 79: 933-935.

SMIT N.J., DAVIES A.J. 2001: An encapsulated haemogregarine from the evileye pufferfish in South Africa. J. Mar. Biol. Assoc. U.K. 81: 751-754.

SMIT N.J., DAVIES A.J. 2004: The curious life-style of the parasitic stages of gnathiid isopods. Adv. Parasitol. 58: 289-391.

SMIT N.J., DAVIES A.J. 2005: Intraerythrocytic merogony in Haemogregarina koppiensis (Apicomplexa: Adeleorina: Haemogregarinidae). Folia Parasitol. 52: 277-278.

SMIT N.J., EIRAS J.C., RANZANI-PAIVA M.J.T., DAVIES A.J. 2002: A Desseria sp. from flathead mullet in South Africa. J. Mar. Biol. Assoc. U.K. 82: 675-676.

SMIT N.J., VAN AS J.G., BASSON L. 1999: A redescription of the adult male and praniza of Gnathia africana Barnard, 1914 (Crustacea, Isopoda, Gnathiidae) from southern Africa. Folia Parasitol. 46: 229-240.

SMIT N.J., VAN AS J.G., DAVIES A.J. 2003: Taxonomic reevaluation of the South African fish haemogregarine Desseria fragilis. J. Parasitol. 89: 151-153.

SMIT N.J., VAN AS J.G., DAVIES A.J. 2004: Trypanosomes from the Okavango Delta, Botswana. Folia Parasitol. 51: 299-303.

SO B.F.K. 1972: Marine fish haematozoa from Newfoundland waters. Can. J. Zool. 50: 543-554

YELD E.M., SMIT N.J. 2006: A new species of Trypanosoma (Kinetoplastida: Trypanosomatidae) infecting catsharks from South Africa. J. Mar. Biol. Assoc. U.K. 86: 829-833.

Accepted 30 October 2006 